\title{
The darker side of raw milk spoiling psychrotrophs
}

\author{
Patricia Munsch-Alatossava and Tapani Alatossava \\ University of Helsinki, Department of Food Technology, PO Box 66, 00014 University of Helsinki, \\ patricia.munsch@helsinki.fi.ttapani.alatossava@helsinki.fi
}

\begin{abstract}
Summary
In general, the quality of raw milk and of dairy products has been considerably improved by the refrigeration on farms, and in processing plants. Unfortunately, the current practices for the collection and the storage of the raw milk favour the growth of psychrotrophic bacteria, able to grow below $7^{\circ} \mathrm{C}$, regardless of their optimal growth temperature. Besides their rapid growth ability in refrigerated milk, psychrotrophs produce heat stable extracellular proteases, lipases, phospholipases. Pseudomonas spp. constitute the predominant microorganisms limiting the shelf life of processed fluid at $4^{\circ} \mathrm{C}$.

In our studies, 64 isolates, selected from 13 raw-milk samples in Finland (that originate from farm, lorry or silo tanks) were characterized by the determination of their spoilage and phenotypic features. Phenotypic characterization of the isolates was mainly performed with API 20NE and BIOLOG GN2 identification systems; the results were system-dependent, although the presence of representatives of the Pseudomonas genus (for the majority of the isolates) was suggested by both systems; moreover, a significant number of isolates were partially identified as members of Stenotrophomonas, Burkholderia and Acinetobacter genera. All three genera comprise species considered in recent reports as emerging pathogens, that carry innate resistance to antibiotics. There is a general consensus that the widespread use of antibiotics has imposed a strong selective pressure that contributed to the emergence of multidrug resistant microorganisms. In the context of the increasing prevalence of antibiotic resistant bacteria, we evaluated the distribution of antibiotic resistant traits among the group of psychrotrophs retrieved from the raw milk samples

The results obtained, with the ATB ${ }^{\circledR}$ PSE system (composed of a panel of $17 \beta$-lactams and non- $\beta$-lactams antibiotics, representatives of 5 classes), designed to investigate the pseudomonads susceptibility/resistance, revealed that the majority of raw milk psychrotrophs, besides exhibiting spoilage features, also harboured antibiotic multiresistant traits.
\end{abstract}

Key words: raw milk, psychrotrophs, pseudomonads, antibiotic resistance 


\section{Introduction}

The current practices for the collection and storage of the raw milk favour the growth of psychrotrophic bacteria, able to grow below $7^{\circ} \mathrm{C}$, regardless of their optimal growth temperature. The psychrotrophs from refrigerated milk include both Gram-negative and Gram-positive bacteria, belonging to numerous genera. Pseudomonas spp. are the most common organisms in raw or pasteurized milk at the time of the spoilage (Sørhaug and Stepaniak 1997); they constitute the predominant micro-organisms limiting the shelf life of processed fluid milk at $4^{\circ} \mathrm{C}$. They comprise $P$. fluorescens, $P$. putida, $P$. fragi, $P$. putrefaciens, less frequently $P$. aeruginosa (Gilmour and Rowe 1990). Significant contaminations by pseudomonads occur due to inadequately sanitized surfaces of milking, storage and transporting equipments. Furthermore post-pasteurization contaminations may happen at the filling operation (Mac Phee and Griffiths 2002).

Besides their rapid growth ability in refrigerated milk, psychrotrophs produce heat stable extracellular proteases, lipases and phospholipases: some enzymes can survive pasteurization and even UHT heat treatments (Braun et al. 1999). Pseudomonas spp. are the primary concern with regard to lipolytic degradation of milk fat (MacPhee and Griffiths 2002). The lipases, by hydrolyzing triglycerides, produce flavour defects associated with fat breakdown in cream, butter, cheese and UHT products. The lecithinases or other phospholipases are able to disrupt the integrity of the milk fat globule membrane (MFGM), and expose the fat to degradation by native milk lipases, resulting in physical degradation of the emulsion in milk. Most of the lipases retain some of their activity after pasteurization and even after UHT treatment (Deeth 2002). Proteases are associated with bitterness in milk, gelation of UHT sterilized milk and reduced yield of cheese. Most of the proteases are able to degrade $\kappa-, \alpha_{\mathrm{s} 1}$ and $\beta$ caseins; they are remarkable heat stable (Mac Phee and Griffiths 2002).

In our study, we attempted to characterize some of the spoilage psychrotrophs present in raw milk along the cold chain of milk transportation (from farm, lorry, and silo) in Finland. We tested mainly two phenotypic identification systems (API 20NE and BIOLOG). In the context of the increasing prevalence of antibiotic resistant bacteria, we also evaluated the distribution of antibiotic resistant traits among the group of psychrotrophs retrieved from the raw milk samples.

\section{Materials and Methods}

Raw milk

The samples were obtained from Finnish farms (5), lorries (3), or silos (2). Total counts were determined on PCA (Plate Count Agar); the plates were incubated whether at $7{ }^{\circ} \mathrm{C}$ or at $25^{\circ} \mathrm{C}$.

\section{Spoilage features}

The production of extracellular enzymes was detected by agar diffusion assays: single colonies underwent a fast screening; if of interest the strain was purified by 3 successive transfers on PCA plates and tested repeatedly on the different agar plates: PCA supplemented with skim milk (for proteases), Tributyrin based agar (for lipases), Egg Yolk based agar (for lecithinases), Red blood agar (for hemolytic feature).

\section{Phenotypic identification}

The studies were performed with API 20NE and API 50CH strips (BioMérieux, Marcy 1'Etoile, France) and with BIOLOG plates (Biolog, Hayward, California).

\section{Antibiotic resistance}

The in-vitro resistance/susceptibility of the isolates was determined with ATB®PSE strips, according to the manufacturer' $\mathrm{s}$ instructions (BioMérieux, Marcy l'Etoile). P. aeruginosa ATCC 27853 was used as the quality control strain in our studies. Two critical concentrations enabled to classify the isolates into three categories (susceptible, intermediate, or resistant). 


\section{Results and discussion}

Psychrotrophs and spoilage features

Six raw milk samples (originating from two farms, two lorries and two silos) were more widely analysed; the spoilage features of 349 isolates are detailed below (Figure 1).

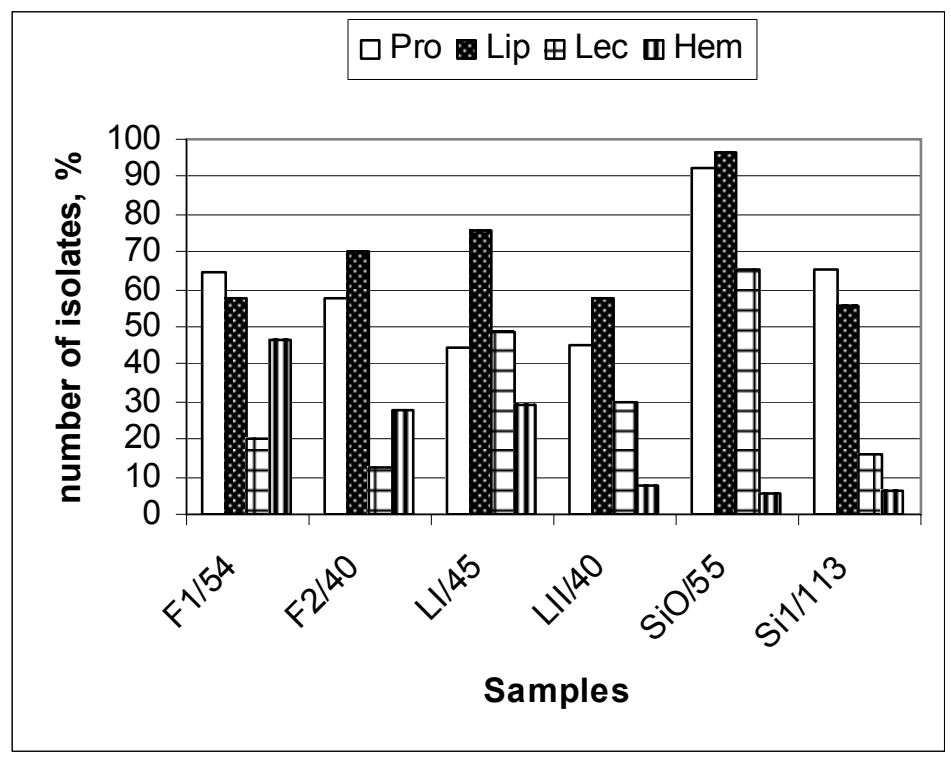

Figure 1: Percentage of raw milk isolates that expressed spoilage and hemolytic features ( $F$, farms: L, lorries; S, silos). Symbols: Pro, Lip, Lec, Hem for proteolytic, lipolytic, lecithinase positive, hemolytic respectively.

\section{Metabolic profiling}

Considering the inventory of the species retrieved from the raw milk samples, the phenotypic identification systems were not producing satisfactory results, since the identity of many isolates remained doubtful or controversial (Table 1). Hence genotyping methods should be carried out in order to clarify the taxonomic status of the considered isolates.

\section{Antibiotic resistance}

Half of the 56 psychrotrophs, retrieved from raw milk samples, were resistant to at least six antibiotics; two isolates were resistant to 12 antibiotics, and one isolate was only susceptible to 2 of the 17 antibiotics constituent of the ATB®PSE strip (Figure 2).

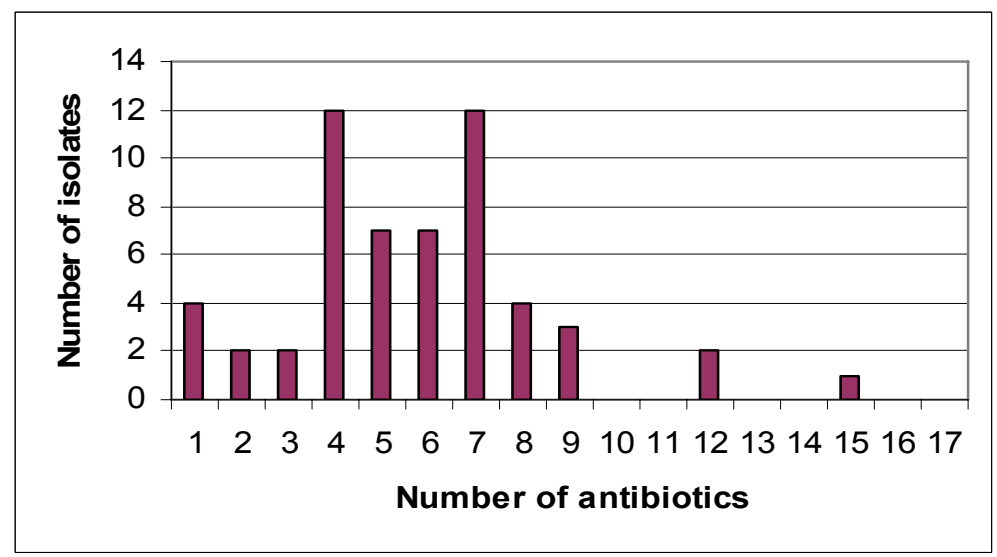

Figure 2: Breadth of resistance: number of isolates found resistant to a certain number of antibiotics (ranging from 1 to 17) as determined by the ATB®PSE system. 
Table 1: Phenotypic characterization of the selected raw milk isolates:

Symbols: bold-italic /identification at the genus or species level; italic/ low discriminated or doubtful profiles; ? not identified.

FARM ISOLATES (29):

\begin{tabular}{|c|c|c|}
\hline \multirow{3}{*}{$\begin{array}{l}\text { No growth at } 4^{\circ} \mathrm{C} \text { or } 7^{\circ} \mathrm{C} \\
(14 \%)\end{array}$} & API 20NE & BIOLOG \\
\hline & P. aeruginosa (1) & P. aeruginosa (1) \\
\hline & $\begin{array}{l}\text { Stenotrophomonas maltophilia (2) } \\
? \text { (1) }\end{array}$ & $\begin{array}{l}\text { Stenotrophomonas maltophilia (2) } \\
\text { Yersinia mollaretti (1) }\end{array}$ \\
\hline \multirow[t]{4}{*}{$\begin{array}{l}\text { Only growth at } 7^{\circ} \mathrm{C} \\
(24 \%)\end{array}$} & Stenotrophomonas maltophilia (2) & $\begin{array}{l}\text { Stenotrophomonas maltophilia (1)- } \\
\text { Aquaspirillum dispar (1) }\end{array}$ \\
\hline & Acinetobacter (3) & A. johnsonii (2)- A. johnsonii(1) \\
\hline & A. johnsonii (1) & Burhkholderia vietnamiensis (1) \\
\hline & A. baumanii (1) & A. baumanii (1) \\
\hline \multirow{7}{*}{$\begin{array}{l}\text { Growth at } 4^{\circ} \mathrm{C} \text { and } 7^{\circ} \mathrm{C} \\
(62 \%)\end{array}$} & S. maltophilia (1) & S. maltophilia (1) \\
\hline & P. fluorescens (6) & P. fluorescens $(1)-P$. tolaasii $(5)$ \\
\hline & Pseudomonas (1) & Pseudomonas (1) \\
\hline & Burkholderia cepacia (1) & Serratia rubidae (1) \\
\hline & B. cepacia $(5)$ & $\begin{array}{l}\text { Enterobacter aerogenes }(2)- \\
\text { P. logei }(1)-P . \text { logei }(1)-?(1)\end{array}$ \\
\hline & Chryseomonas (1) & Photobacterium logei (1) \\
\hline & $?(3)$ & $\begin{array}{l}\text { Pseudomonas (2) - Klebsiella } \\
\text { planticola }(1)\end{array}$ \\
\hline
\end{tabular}

LORRY ISOLATES (17):

\begin{tabular}{|lll|}
\hline $\begin{array}{l}\text { Growth at } \mathbf{4}^{\circ} \mathbf{C} \text { and } 7^{\circ} \mathbf{C} \\
(\mathbf{1 0 0} \%)\end{array}$ & $\begin{array}{l}\text { API 20NE } \\
\text { P. fluorescens (9) }\end{array}$ & $\begin{array}{l}\text { BIOLOG } \\
\text { Pseudomonas (9) }\end{array}$ \\
$\begin{array}{l}\text { P. fluorescens (3) } \\
\text { P. putida (2) } \\
\text { Burkholderia pseudomallei (3) }\end{array}$ & $\begin{array}{l}\text { P. fluorescens bvC (3) } \\
\text { P. putida (1) - Pseudomonas sp (1) }\end{array}$ \\
& \\
\end{tabular}

SiLO ISOLATES (18):

\begin{tabular}{|c|c|c|}
\hline $\begin{array}{l}\text { Growth at } 4^{\circ} \mathrm{C} \text { and } 7^{\circ} \mathrm{C} \\
(100 \%)\end{array}$ & $\begin{array}{l}\text { API 20NE } \\
\text { P. fluorescens (12) }\end{array}$ & $\begin{array}{l}\text { BIOLOG } \\
\text { P. fluorescens (2) - P. tolaasii (1)- } \\
\text { Pseudomonas (6)- B. } \\
\text { cocovenenans (1) - Neisseria (1)- } \\
\text { ?(1) }\end{array}$ \\
\hline & $\begin{array}{l}\text { P. fluorescens }(1) \\
\text { B. cepacia }(1) \\
\text { B. cepacia }(1) \\
\text { ? (2) } \\
\text { Chryseomonas }(1)\end{array}$ & $\begin{array}{l}\text { Pseudomonas (1) } \\
\text { Pseudomonas (1) } \\
\text { P. tolaasii (1) } \\
\text { P. fluorescens (1) - Pseudomonas } \\
\text { (1) } \\
\text { Photobacterium (1) }\end{array}$ \\
\hline
\end{tabular}




\section{Conclusion}

The present study was undertaken in order to draw up some inventory of the species that may be spoiling raw milk along the cold chain of storage and transportation in Finland. The use of the phenotypic identification systems was conclusive for some strains, however the identity of many isolates remained doubtful or controversial. Despite no precise assignment, some isolates were attributed by either one or the other system to Acinetobacter genus, to Stenotrophomonas and Burkholderia genera (former Pseudomonas) being described as emerging pathogens, as nosocomial opportunistic pathogens that exhibit multiresistant traits (Alonso et al. 2000, Levy et al. 2002). The results obtained with the ATB®PSE strips, designed to investigate the pseudomonads susceptibility/resistance, revealed that many psychrotrophs, besides exhibiting spoilage features, were also multiresistant.

\section{Acknowledgements}

The studies were supported by the University of Helsinki and by the Walter Ehrström Foundation. The technical assistance of Mrs Sanna Murtomäki-Repo (BioMérieux, Finland) and Mrs Murielle Barriol (BioMérieux, France) was highly appreciated. We are grateful to Dr. Leena Suominen, and to Dr. Kristina Lindström for their assistance in Biolog analyses.

\section{References}

Alonso, A., Sanchez, P. \& Martinez J.L. 2000. Stenotrophomonas maltophilia D457R contains a cluster of genes from Gram-positive bacteria involved in antibiotic and heavy metal resistance. Antimicrob. Agents and Chemother. 44: 1778-1782.

Braun, P., Fehlhaber, K., Klug, C.\& Kopp K. 1999. Investigations into the activity of enzymes produced by spoilage-causing bacteria: a possible basis for improved shelf-life estimation. Food Microbiol. 16: 531-540.

Deeth, H.C. 2002. Lipolysis. Pages 1595-1601. In Encyclopedia of Dairy Sciences. Vol 1, ed. H. Roginsky, J.W. Fuquay, P.F. Fox, Academic Press.

Gilmour, A.\& and Rowe M.T. 1990. Microorganisms associated with milk. Pages 37-75. In The Microbiology of Milk Vol.1, Robinson RK, $2^{\text {nd }}$ ed. Dairy Microbiology, Elsevier Applied Science, London.

Levy, S.B. 2002. Factors impacting on the problem of antibiotic resistance. J. Antimicrobial. Chemoth. 49: 2530.

Mac Phee, J.D.\& Griffiths M.W. 2002. Psychrotrophic bacteria. Pseudomonas spp. Pages 2340-2351. In Encyclopedia of Dairy Sciences, Vol 4, ed. H. Roginsky, J.W Fuquay, P.F. Fox, Academic Press.

Sørhaug, T. \& Stepaniak L. 1997. Psychrotrophs and their enzymes in milk and dairy products: quality aspects. Trends in Food and Sci. Technol. 8: 35-40. 